\title{
In utero exposure to tributyltin chloride differentially alters male and female fetal gonad morphology and gene expression profiles in the Sprague-Dawley rat
}

\author{
Osama Kishta ${ }^{\mathrm{a}}$, Adedayo Adeeko ${ }^{\mathrm{b}}$, Daming Li ${ }^{\mathrm{b}}$, Trang Luu ${ }^{\mathrm{b}}$, James R. Brawer ${ }^{\mathrm{a}}$, \\ Carlos Morales $^{\mathrm{a}}$, Louis Hermo ${ }^{\mathrm{a}}$, Bernard Robaire ${ }^{\mathrm{b}, \mathrm{c}}$, Barbara F. Hales ${ }^{\mathrm{b}}$, \\ Johanna Barthelemy ${ }^{\mathrm{e}}$, Daniel G. Cyr ${ }^{\mathrm{a}, \mathrm{e}}$, Jacquetta M. Trasler ${ }^{\mathrm{b}, \mathrm{d}, *}$ \\ ${ }^{a}$ Department of Anatomy and Cell Biology, McGill University, Montreal, Quebec H3G 1Y6, Canada \\ ${ }^{\mathrm{b}}$ Department of Pharmacology and Therapeutics, McGill University, Montreal, Quebec H3G 1Y6, Canada \\ ${ }^{\mathrm{c}}$ Department of Obstetrics and Gynecology, McGill University, Montreal, Quebec H3G 1Y6, Canada \\ d Department of Pediatrics, and Human Genetics, McGill University, Montreal, Quebec H3G 1Y6, Canada \\ ${ }^{\mathrm{e}}$ INRS-Institut Armand-Frappier, Université du Québec, Pointe-Claire, Québec H9R 1G6, Canada \\ Received 4 December 2004; received in revised form 22 August 2006; accepted 22 August 2006 \\ Available online 16 September 2006
}

\begin{abstract}
Tributyltin (TBT) is an environmental contaminant commonly used in anti-fouling agents for boats, as well as a by-product from several industrial processes. It has been shown to accumulate in organisms living in areas with heavy maritime traffic thereby entering the food chain. Here, we determined the consequences of in utero exposure to TBT on the developing fetal gonads in the Sprague-Dawley rat. Timed pregnant rats were gavaged either with vehicle or TBT $(0.25,2.5,10$ or $20 \mathrm{mg} / \mathrm{kg}$ ) from days 0 to 19 or 8 to 19 of gestation. On gestational day 20 , dams were sacrificed; fetal testes and ovaries were processed for light (LM) or electron microscopic (EM) evaluation and RNA was prepared for gene expression profiling. At the highest doses of TBT the number of Sertoli cells and gonocytes was reduced, there were large intracellular spaces between Sertoli cells and gonocytes and there was an increased abundance of lipid droplets in the Sertoli cells; EM studies revealed abnormally dilated endoplasmic reticulum in Sertoli cells and gonocytes. In the intertubular region between adjacent interstitial cells, immunostaining for the gap junctional protein connexin 43 was strong in controls, whereas it was reduced or completely absent in treated rats. In the ovaries, TBT $(20 \mathrm{mg} / \mathrm{kg}$, days $0-19 ; 10 \mathrm{mg} / \mathrm{kg}$, days $8-19)$ reduced the number of germ cells by $44 \%$ and $46 \%$, respectively. On examining gene expression profiles in the testis, 40 genes out of 1176 tested were upregulated more than two-fold over control. While no genes were upregulated in the TBT exposed fetal ovary, eight genes were downregulated. In conclusion, in utero exposure to TBT resulted in gender-specific alterations in gonadal development and gene expression profiles suggesting that there may be different adaptive changes to toxicity in developing male and female rats. (C) 2006 Elsevier Inc. All rights reserved.
\end{abstract}

Keywords: Organotin; Reproductive biology; Ovary; Testis; Developmental biology; Environment

\section{Introduction}

Tributyltin (TBT), is an environmental pollutant that is most widely used as a defouling agent for paints and for coating structures exposed to the aquatic environment such as ships, oil rigs and water intake pipes [1]. Bioaccumulation of TBT occurs in

\footnotetext{
* Corresponding author at: Montreal Children's Hospital Research Institute, 2300 Tupper Street, Montreal, Quebec H3H 1P3, Canada.

Tel.: +1 514412 4400x25235; fax: +1 5144124331 .

E-mail address: jacquetta.trasler@mcgill.ca (J.M. Trasler).
}

aquatic and wildlife species due to the lipophilic and ionic properties of the compound and its slow elimination [2]. TBT enters the human food chain mainly through contaminated marine and freshwater species, industrial effluents [3], domestic use as a wood preservative, leaching from PVC pipes, and inhalation and absorption through the skin [4]. In a recent study, Forsyth and Casey [5] found butyltin in 62 of 74 mollusc products purchased from major supermarket outlets in 7 cities across Canada. TBT was detected in 41 samples, with levels up to $233 \mathrm{ng} \mathrm{g}^{-1}$.

TBT is known to cause imposex in marine species. Imposex is a condition in which female sex organs are masculinized 
and animals become sterile due to the development of nonfunctional male secondary characteristics [6]. Although the mechanisms underlying TBT-induced imposex are not fully understood, TBT is thought to act as a neurotoxin that alters the release of the neuropeptide hormone, Penis Morphogenic Factor [7]. Other possibilities include the inhibition of aromatization and conjugation of testosterone and inhibition of several steroidogenic enzymes by TBT $[8,9]$.

Mammals are also sensitive to the toxic effects of TBT. Incidences of accidental and occupational human exposures have been reported. Symptoms include mucous membrane irritation [4], headaches, nosebleeds, nausea and vomiting [10], as well as significantly greater frequencies of cycles of depression and destructive rage [11]. Exposure of rodents to high doses of TBT appears to cause irreversible brain damage [12]. Immunotoxic effects of TBT include atrophy of the thymus and spleen, decreased T-lymphocyte populations, suppression of natural killer cell activity, and lowered resistance to infections in rats and mice [13-15]. TBT can also alter circulating levels of thyroid hormones suggesting that it can significantly alter many developmental processes that are thyroid-hormone dependant, including the reproductive system $[16,17]$.

TBT inhibits human aromatase activity in a granulosa celllike tumor cell line and transfected cells $[9,18,19]$ and, at noncytotoxic doses, enhances aromatase activity in human placental choriocarcinoma cells [20], raising the possibility of such interactions during exposure. Exposure to organotins can affect mammalian reproduction. Evidence of testicular effects were reported in a two-generation toxicity study where daily doses of $10 \mathrm{mg} / \mathrm{kg}$ of TBT affected both testicular histology and sperm counts; the fact that more severe effects were seen in the second generation suggested effects of gestational exposure [21]. Transplacental transfer of TBT has been documented [22]. In rats, studies from our group and others have shown that in utero exposure to high doses of TBT led to decreased maternal weight gain and fetal weights, induced pre- or post-implantation losses [16,23-25] and caused fetal toxicity [26]. Although gestational exposure to TBT altered anogenital distance in both postnatal day 1 female pups [27] and gestational day 20 male rat fetuses [16], sex ratio was not altered in these studies. However, the effects of isolated in utero exposure to TBT on the development of the fetal gonad are yet to be reported. Given the effects of TBT on the functions of a wide range of mammalian cells and organs, in the current study we investigated the consequences of exposure to TBT during pregnancy on the histology and gene expression profiles of fetal gonads. In a previous study, we reported the effects of the same dosing regimen on TBT concentrations in maternal blood, maternal weight gain and pregnancy outcome [16].

\section{Materials and methods}

\subsection{Chemicals}

Tributyltin chloride (TBT, 96\%) was purchased from Sigma-Aldrich Canada (Oakville, Ont.). Olive oil, the vehicle used, was purchased from Aldrich Diagnostics USA (St. Louis, MO).

\subsection{Animals and treatment}

Male (300-350g) and female (200-250g) Sprague-Dawley rats were obtained from Charles River Canada (St. Constant, Quebec, Canada) and housed in the McIntyre Medical Building Animal Resource Centre at McGill University with a $14 \mathrm{~h}$ light: $10 \mathrm{~h}$ dark cycle. The animals had free access to food (Purina chow 5012, Mondou Feeds, Montreal, Canada) and water; all animal handling and care followed the guidelines of the Canadian Council on Animal Care.

Virgin female rats in proestrus were mated overnight with males. Successful mating was indicated by the presence of spermatozoa in the vaginal smear on the following morning (day 0 of pregnancy). Pregnant rats were randomly divided into groups that were given a daily dose of vehicle (control; $n=25)$ or TBT $(0.25$, $2.5,10$ or $20 \mathrm{mg} / \mathrm{kg} ; n=12 /$ treatment) by gavage either from days 0 to 19 or 8 to 19 of pregnancy. All TBT solutions were prepared fresh daily. Dams were weighed on days 0 and 20 of pregnancy and once every 3 days in that interval, the volume and dose of TBT administered was adjusted to $5 \mathrm{ml} / \mathrm{kg}$ of body weight.

On day 20 of pregnancy, dams were sacrificed and the uterus was dissected out. The fetuses were carefully separated, weighed and sexed. Testes and ovaries from fetuses belonging to different litters were fixed in either Bouins solution or glutaraldehyde for subsequent histological processing and analysis. Testes or ovaries were pooled from individual fetuses in each litter, flash frozen in liquid nitrogen and stored at $-80^{\circ} \mathrm{C}$ for gene expression profiling and analysis; pooled testes and ovaries from control and treated litters $(n=5$ separate litters for each group) were used for gene array analysis.

\subsection{Light microscopy}

Fetal testes and ovaries ( $n=3-8$ per group) were fixed by immersion in Bouins fixative for $2 \mathrm{~h}$ and stored in $70 \%$ alcohol until further histological processing. Gonads were dehydrated in a graded series of alcohol and embedded in paraffin. Sections of testicular tissue $(5 \mu \mathrm{m})$ were cut, mounted on glass slides and stained with hematoxylin and eosin (H\&E). A similar number of testes and ovaries were fixed by immersion in $2.5 \%$ glutaraldehyde, buffered with $0.1 \mathrm{M}$ sodium cacodylate for $24 \mathrm{~h}$ and washed overnight in cacodylate buffer. On the following day, the tissues were post-fixed in $2 \%$ osmium tetroxide $\left(\mathrm{OsO}_{4}\right)$ for $2 \mathrm{~h}$, dehydrated in a graded series of methanol and embedded in Epon. Semithin testicular and ovarian sections were sectioned $(0.5 \mu \mathrm{m})$ and stained with toluidine blue for light microscopic (LM) viewing. Histological data were analyzed by two-way ANOVA followed by Tukey and $t$-tests.

\subsection{Electron microscopy}

For electron microscope (EM) analysis, ultrathin Epon sections (silver interference color) from selected areas were cut using a diamond knife. The ultrathin sections were subsequently mounted on copper grids, stained with uranyl acetate and lead citrate, viewed and photographed with a Philips 400 EM.

\subsection{Quantitative analysis of gonocytes and Sertoli cells}

Toluidine blue-stained sections of fetal testes ( $n=5-8$ animals/group) were photographed. Briefly, four micrographs of different fields per testis were taken at a magnification of $400 \times$. Seminiferous tubule area was calculated using a Zeiss MOP- 3 instrument and averages obtained. The MOP- 3 instrument software was used to measure area as manually defined by a stylus connected to the machine. The nucleoli of gonocytes and Sertoli cells within the measured area of seminiferous tubules were scored and expressed as number of gonocytes or Sertoli cells per unit area of seminiferous tubule (unit area $=0.01 \mathrm{~mm}^{2}$ ). These two values were used to calculate the ratio of Sertoli cells/gonocytes for each animal group.

\subsection{Immunostaining and quantitation of Leydig cells}

Unstained paraffin sections $(5 \mu \mathrm{m})$ of fetal testes were deparaffinized in histoclear ${ }^{\mathrm{TM}}$, rehydrated in a graded series of ethanol and immersed in a solution of glycine ( $5.63 \mathrm{~g}$ in $250 \mathrm{ml}$ of $\mathrm{dH}_{2} \mathrm{O}$ ) for $5 \mathrm{~min}$. Non-specific binding was prevented by blocking sections in $5 \%$ goat serum for $15 \mathrm{~min}$ at $37^{\circ} \mathrm{C} .3 \beta$-HSD

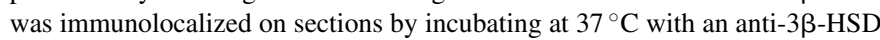


antibody [28] at a dilution of 1:100 (in Tris-buffered saline-TBS; $\mathrm{pH}$ 7.4) for $90 \mathrm{~min}$. Sections were rinsed with three changes of TBS containing $0.1 \%$ Tween-20 (TWBS) for $2 \mathrm{~min}$ each. All sections were blocked in 5\% goat serum at $37^{\circ} \mathrm{C}$ for $15 \mathrm{~min}$ and then incubated with goat anti-rabbit IgG conjugated to peroxidase (Sigma Chemical, St. Louis, MO) at a dilution of 1:250 in TBS for $30 \mathrm{~min}$. Sections were then rinsed in three changes of TWBS at $2 \mathrm{~min}$ per rinse, then incubated for $10 \mathrm{~min}$ in TBS containing $0.05 \%$ 3,3-diaminobenzidine tetrahydrochloride, $0.03 \%$ hydrogen peroxide, and $0.1 \mathrm{M}$ imidazole ( $\mathrm{pH}$ 7.6). The sections were rinsed with two changes of distilled water and then counterstained with $0.1 \%$ methylene blue for $15 \mathrm{~s}$, dehydrated in ethanol, immersed in xylene and had cover slips mounted with Permount ${ }^{\mathrm{TM}}$. The specificity of the antibody was verified by the incubation of sections without the primary antibody or with normal rabbit serum. Three different fields of interstitial space were photographed per individual control and experimental testis $(10$ and $20 \mathrm{mg} / \mathrm{kg}$ TBT, $n=6-10$ animals). To calculate interstitial space area, random fields were outlined and measured (for each group) using a Zeiss MOP-3 instrument in a similar manner as described above for the seminiferous tubules. Leydig cells were identified by their $3 \beta$-HSD-immunostained cytoplasm counted and expressed as number of cells/unit area $\left(0.1 \mathrm{~mm}^{2}\right)$.

Immunocytochemical localization of $\mathrm{Cx} 43$ in the fetal testis and ovary was done using a rabbit polyclonal $\mathrm{Cx} 43$ antiserum (Zymed Laboratories, Seattle, WA). Antibody binding to $\mathrm{Cx} 43$ was detected using the horseradish peroxidase method as outlined above using a horseradish peroxidase conjugated anti-rabbit secondary antibody (Sigma Chemical). Slides incubated with normal rabbit antiserum were used as a negative control.

\subsection{Quantitative analysis of ovarian germ cells}

Germ cells were counted from hematoxylin and eosin-stained paraffin sections of control and treated ovaries and expressed as number of cells per unit area. Briefly, one ovary per fetus was photographed at a magnification of $840 \times$. Each micrograph represented a rectangular area of $0.0319 \mathrm{~mm}^{2}$ taken from the center of the ovary; germ cells within this area were identified and counted.

\subsection{Quantitation of apoptotic cells in fetal ovaries}

Apoptotic cells were detected using terminal deoxynucleotidyl transferasemediated dUTP nick end-labeling (TUNEL) in unstained sections. Unstained sections were deparaffinized in xylene, rehydrated in a graded ethanol series, washed in PBS for $5 \mathrm{~min}$ and stained for apoptotic cells according to the ApopTag (Intergen, Norcross, GA) manual and specifications. Sections were photographed at a magnification of $168 \times$ and TUNEL-stained cells were identified and counted in a single section of each ovary $(n=6-9)$. The area of each section was determined using a Zeiss MOP-3 and the number of apoptotic cells per $0.01 \mathrm{~mm}^{2}$ of ovary was calculated.

\subsection{Elemental histology}

A JEOL 2000 FX (Tokyo, Japan) electron microscope equipped with an X-ray energy dispersion spectroscope (PGT IV, USA) with a resolution of $30 \mathrm{~nm}$ was used to determine the chemical composition [29,30] of dense bodies observed in germ and stromal cells of fetal ovaries exposed to TBT.

\subsection{RNA extraction}

Total RNA was extracted from the testes and ovaries of fetuses obtained from gestational day 20 dams that were either gavaged with vehicle alone or $20 \mathrm{mg} / \mathrm{kg}$ TBT from days 0 to 19 of gestation. The Qiagen RNAeasy kit and protocols, including column DNase treatment (Qiagen, Mississauga, Canada), were used for the extraction. The RNA was assessed for absence of genomic DNA and quality (28S-18S ratios of 2:1) by electrophoresis in agarose-formaldehyde gels.

\subsection{Preparation of radiolabelled $c D N A$ and hybridization}

Total RNA $(3.5 \mu \mathrm{g})$ was reverse transcribed with Moloney-murine-leukemia virus reverse transcriptase (MMLV-RT) in the presence of $\left[\alpha-{ }^{32} \mathrm{P}\right] \mathrm{dATP}$ (Amer- sham Pharmacia Biotech, Baie d'Urfé, Québec; $10 \mu \mathrm{Ci} / \mu \mathrm{l})$, as described previously [28]. Probes were purified with nucleospin columns (BD Sciences Clontech, Mountain View, CA) and hybridized to Atlas Rat1.2 Array nylon membranes (BD Sciences Clontech) at $68^{\circ} \mathrm{C}$ overnight. Hybridization and washing conditions were as described previously [31]. RNA was extracted from pooled testes and ovaries of fetuses from five control and five treated dams.

\subsection{Analysis of gene expression}

Hybridization intensity was captured using a phosphorimager (Storm, GE Healthcare Life Sciences, Piscataway, NJ) after a $24 \mathrm{~h}$ exposure of membranes to phosphorimaging intensifying screens. The intensity of each spot was quantified using the Atlas Image TM version 2.0 software; these data were then imported to GeneSpring $^{\text {TM }}$ (version 4.0.7, Agilent Technologies, Palo Alto, CA) for further analysis. For each individual array, the gene detection threshold was set at a raw signal intensity of $2 \times$ the background intensity on that array. To minimize experimental variation, expression values were normalized to the median of all measurements on that individual array (standard experiment-to-experiment normalization). Statistical comparisons were made of TBT exposed as compared to control gonads by Mann-Whitney Rank Sum Test $(p \leq 0.05$ and $p \leq 0.10)$ for genes that had passed a $>2.0$-fold change filter in at least three out of five replicates (each replicate from a separate litter, $n=5$ litters/group). In addition to 'experiment-to-experiment normalization' we applied 'gene-to-gene normalization' to the data to allow for clearer visualization of cluster patterns with all genes being closer on the vertical axis; the gene expression value for each gene was normalized relative to the median of all values taken for that gene in each treatment [31].

\section{Results}

\subsection{Fetal testis}

Semithin sections of testicular tissues fixed in glutaraldehyde and stained with toluidine blue revealed abundant lipid droplets in the cytoplasm of Sertoli cells of the treated animals, particularly in the group treated with 10 and $20 \mathrm{mg} / \mathrm{kg}$ TBT (gestation days $0-19$ and 8-19, respectively). The lipid droplets were more prominent and frequent in the group treated with $20 \mathrm{mg} / \mathrm{kg}$ TBT chloride (Fig. 1). The LM of toluidine blue-stained semithin sections also revealed occasional lipid droplets in the cytoplasm of gonocytes. The lipidic nature of the cytoplasmic droplets was determined by the osmophilia exhibited by these structures. Another abnormality observed in the treated testes, particularly in those exposed to the higher doses of TBT (10 and $20 \mathrm{mg} / \mathrm{kg}$ ) was the presence of large intercellular spaces between gonocytes and Sertoli cells that were rarely seen in the controls (Fig. 1).

Quantitative analysis of gonocytes and Sertoli cells in the seminiferous tubules was done on the different experimental groups to determine the effect of TBT on these cells; the nucleoli (sharply displayed in toluidine blue-stained sections) of both cell types were scored separately. The number of gonocytes was significantly lower only at $10 \mathrm{mg} / \mathrm{kg}$ TBT and when exposure was from days 8 to $19(p=0.003)$ (Table 1$)$. The quantitation of Sertoli cells/unit area of the seminiferous tubules revealed a significant decrease in the fetuses exposed to 10 or $20 \mathrm{mg} / \mathrm{kg}$ TBT on days 0-19 and 8-19 (Table 1).

The quantitative analysis of Leydig cells stained with the anti-3 $\beta$-HSD antibody showed a trend toward a decrease in the number of Leydig cells per unit area of interstitial space in fetuses exposed from gestational days 0 to 19 (Table 1). However, the differences in these values were not significant. 


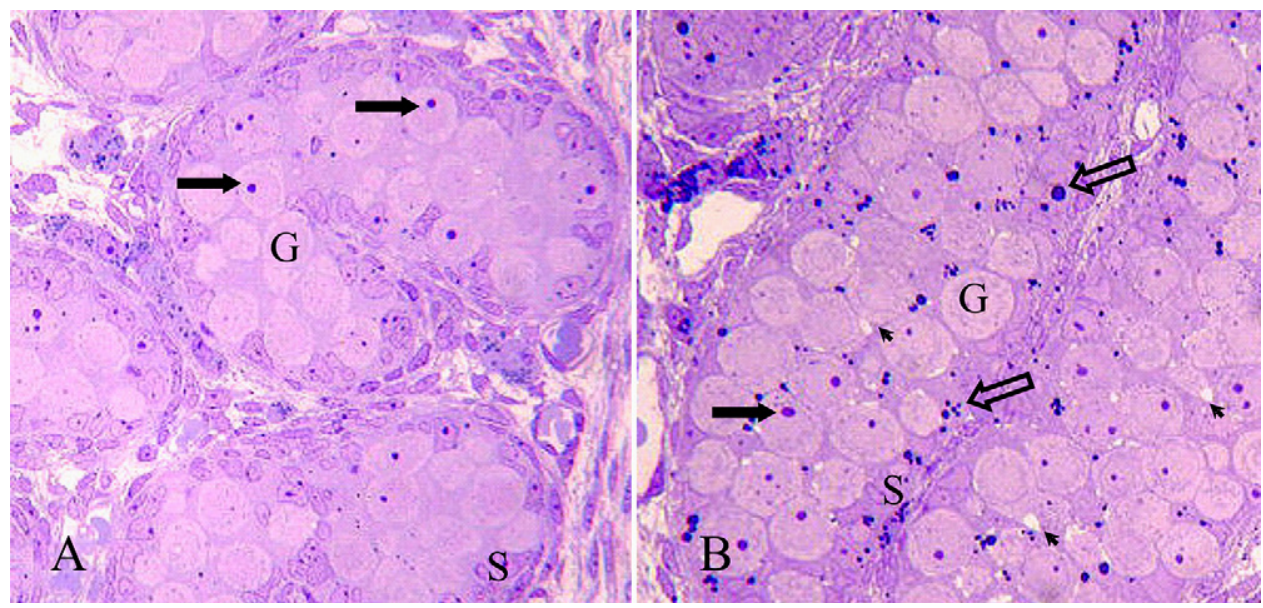

Fig. 1. Testes of 20-day-old fetuses fixed in glutaraldehyde. (A) Control testis and (B) treated testis ( $20 \mathrm{mg} / \mathrm{kg}$ TBT, days 0-19 of gestation). Nucleoli of gonocytes and nucleoli of Sertoli cells seen in the field (solid arrows) were counted for a quantitative analysis. Intercellular spaces (arrow heads) and the accumulation of lipid (open arrows) in the cytoplasm of Sertoli cells (S) and gonocytes (G) are observed in the treated but not in the control testis. 500×.

Table 1

Effects of in utero exposure to tributyltin chloride from gestational days 0 to 19 and 8 to 19 on cell numbers within the testis on gestational day 20

\begin{tabular}{cccc}
\hline Treatment & $\begin{array}{l}\text { Gonocytes } \\
\left(0.1 \mathrm{~mm}^{2}\right)\end{array}$ & $\begin{array}{l}\text { Sertoli cells } \\
\left(0.1 \mathrm{~mm}^{2}\right)\end{array}$ & $\begin{array}{l}\text { Leydig cells } \\
\left(0.1 \mathrm{~mm}^{2}\right)\end{array}$ \\
\hline Control & $63.2 \pm 4.4$ & $88.4 \pm 3.9$ & $54.2 \pm 5.3$ \\
$\begin{array}{c}\text { Days 0-19 } \\
10 \mathrm{mg} / \mathrm{kg}\end{array}$ & $61.5 \pm 2.4$ & $69.9 \pm 4.1^{*}$ & $47.2 \pm 3.7$ \\
$20 \mathrm{mg} / \mathrm{kg}$ & $63.3 \pm 4.1$ & $62.9 \pm 2.5^{*}$ & $44.5 \pm 5.9$ \\
$\begin{array}{l}\text { Days 8-19 } \\
10 \mathrm{mg} / \mathrm{kg}\end{array}$ & $42.9 \pm 3.7^{*}$ & $69.7 \pm 3.4^{*}$ & $52.9 \pm 4.1$ \\
$20 \mathrm{mg} / \mathrm{kg}$ & $60.0 \pm 2.8$ & $62.6 \pm 4.2^{*}$ & - \\
\hline
\end{tabular}

Numbers are mean \pm standard error of mean (S.E.M.). * Significantly different from control. $p \leq 0.05$, ANOVA; - , not determined.

When examined by electron microscopy, the cytoplasm of Sertoli cells and gonocytes of fetuses exposed to 10 or $20 \mathrm{mg} / \mathrm{kg}$ TBT showed the presence of lipids, large intercellular spaces (Fig. 2) and abnormally dilated endoplasmic reticulum (ER)
(Fig. 3). These features were absent in the testes of control fetuses.

In control fetal rat testes, a weak $\mathrm{Cx} 43$ immunoreaction was present between Sertoli cells of the developing testis. A much stronger reaction was present between interstitial cells. In rats exposed to $10 \mathrm{mg} / \mathrm{kg}$ TBT throughout the period of gestation (0-19 days), we noted that $\mathrm{Cx} 43$ immunostaining appeared unaltered between adjacent Sertoli cells (Fig. 4C and D). However, in the intertubular region between adjacent interstitial cells, Cx43 immunostaining was reduced or completely absent; this effect was variable among the testes, sometimes no effect was noted on the staining of Leydig cells. In rats exposed to TBT during organogenesis (8-19 days), $\mathrm{Cx} 43$ immunostaining appeared to be slightly decreased between Sertoli cells (Fig. 4E and F). Furthermore, there was little or no immunoreaction between interstitial Leydig cells. Together, these data indicate that cellular communication via $\mathrm{Cx} 43$ type gap junctions is decreased following in utero exposure to high doses of TBT. This effect was observed for both exposure periods in interstitial Leydig cells while the effects on adjacent Ser-
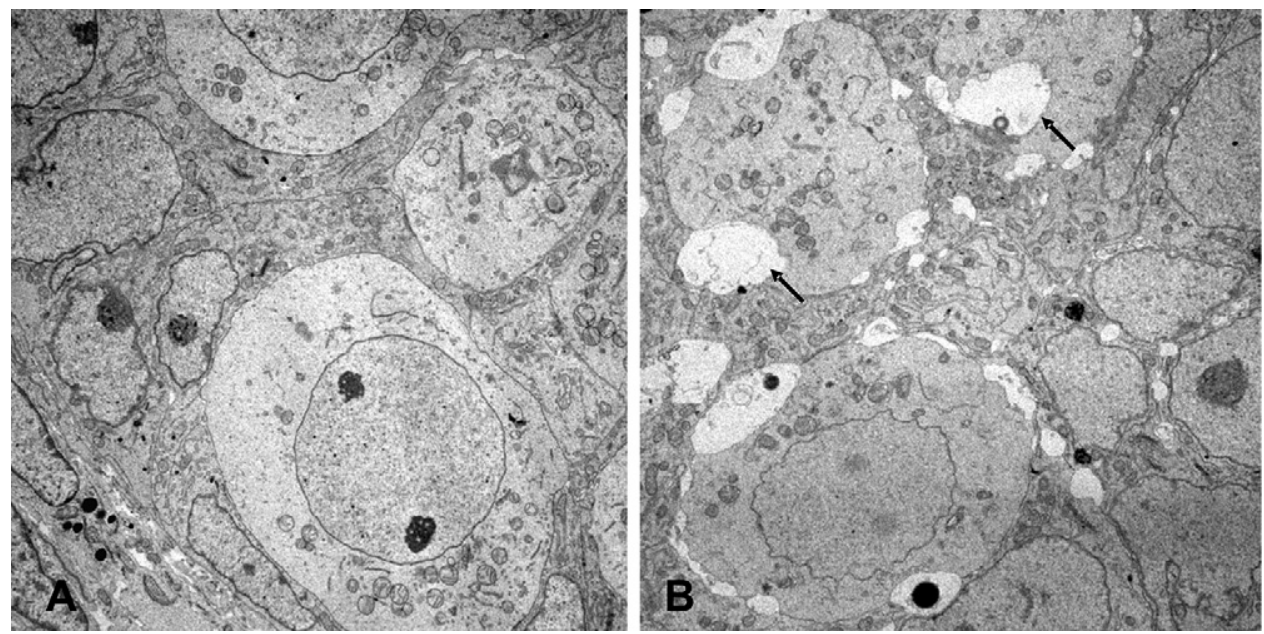

Fig. 2. Electron micrograph of fetal testis fixed in glutaraldehyde. (A) Control. (B) Testis exposed to a maternal dose of $10 \mathrm{mg} / \mathrm{kg}$ of TBT, gestation days $0-19$. Note the presence of intercellular spaces between gonocytes and Sertoli cells (arrows) in the treated testis only. 11,309×. 

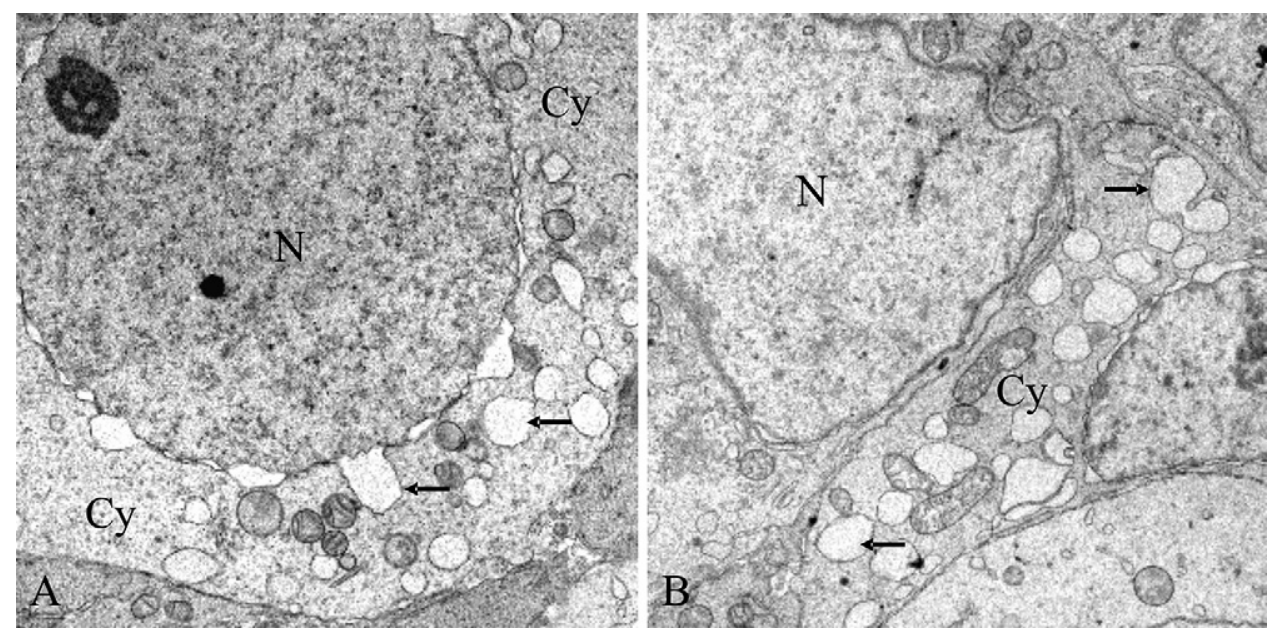

Fig. 3. Electron micrograph of fetal testis fixed in glutaraldehyde and stained with uranyl acetate and lead citrate. (A) Gonocyte and (B) Sertoli cell of a fetus exposed to a maternal dose of $10 \mathrm{mg} / \mathrm{kg}$ TBT from gestational days 0 to 19 . Note abnormally dilated endoplasmic reticulum in both gonocytes and Sertoli cells (arrows). The ER is not dilated in the control testes (see Fig. 2A). N, nucleus; Cy, cytoplasm. 14,465×.

toli cells appeared to occur only during the $8-19$ days exposure period.

\subsection{Fetal ovaries}

A survey of the light micrographs of fetal ovarian sections stained with hematoxylin and eosin indicated the presence, in the ovaries of maternally treated animals, of a large number of germ cells with pyknotic nuclei, typical of degenerating cells. Although these degenerating cells were occasionally seen in the control ovaries, they were more frequent and more prominent in the treated ovaries, particularly at the higher doses (10 and $20 \mathrm{mg} / \mathrm{kg}$ )(Fig. 5).

Quantitative analysis of ovarian cells showed a decrease in the number of germ cells per unit area of fetal ovary (unit area $=0.0319 \mathrm{~mm}^{2}$ ) in both groups that was significant at the highest doses (i.e. at a dose of $20 \mathrm{mg} / \mathrm{kg}$ TBT for the gestation days $0-19$ group and a dose of $10 \mathrm{mg} / \mathrm{kg}$ TBT gestation for the gestation days 8-19 group) (Fig. 6, top). The mean number of germ cells/unit area in these two groups showed a decrease of $43.8 \%$ and $46.1 \%$, respectively, as compared to control values.

The terminal deoxynucleotidyl transferase-mediated dUTP nick end-labeling (TUNEL) method was applied to histological sections of the fetal ovaries in order to determine whether, and to what extent, apoptosis contributed to the reduced number of germ cells in TBT exposed ovaries. Both experimental groups (gestation days 0-19 and 8-19) showed a trend toward increased numbers of apoptotic cells with the higher doses of TBT. In ovaries exposed to $10 \mathrm{mg} / \mathrm{kg}$ of tributyltin (gestation days 0-19), there were significantly more apoptotic cells than in controls (Fig. 6, bottom).

There were no differences in $\mathrm{Cx} 43$ immunostaining in the fetal ovary between control and TBT-treated rats (data not shown).

An EM qualitative survey of the ovaries indicated that myelin figures and dense bodies appeared more common in germ and stromal cells of ovaries exposed to TBT than in controls (data not shown). Energy-dispersive X-ray emission spectroscopy indicated that many of these dense bodies contained iron. Tin was however, not detected.

\subsection{Gene expression profiles in fetal gonads}

As part of our evaluation of the effects of in utero exposure to TBT on the fetal gonads, a profile of genes expressed in the testes and ovaries of control and treated (maternal dose: $20 \mathrm{mg} / \mathrm{kg}$ TBT, days 0-19) gestational day 20 fetuses was obtained. Out of the 1185 genes (including housekeeping genes) on the arrays, 223 were detected in the testes of both the control and the TBT exposed fetuses (Fig. 7); 58 genes were exclusively expressed in the testes of the TBT exposed males while only a few genes (i.e. 5) were exclusively expressed in the control fetal testes. The effects of in utero exposure to TBT on the ovary differed from those in the testis. Approximately equivalent numbers of genes, 230 and 227, respectively, were expressed in the ovaries of control and TBT exposed fetuses; of these, 215 were detected in the ovaries of both the control and the TBT exposed fetuses, with equivalent numbers expressed exclusively in control (i.e. 15) or TBT exposed (i.e. 12) gonads (Fig. 7).

Compared to the control, the testes of fetuses exposed to TBT showed an increased expression by more than two-fold, of 40 genes (Table 2); no genes showed a comparable decrease in their expression. The changes in the profile of gene expression were completely different in the ovary. While no genes were upregulated in the fetal ovary after TBT exposure, eight genes were downregulated (Table 3). Interestingly, the expression intensity of integrin beta 1 was changed in the opposite direction by greater than 2.5 -fold in the fetal testis (upregulated) and ovary (downregulated) (Tables 2 and 3, Fig. 8). Amongst the 40 genes upregulated in the fetal testis following TBT exposure, a number were involved in the stress response. A comparison of the effects of TBT exposure in the fetal testis and ovary on a number of the stress response-related genes is shown in Fig. 8. Microsomal glutathione $S$-transferase 1, superoxide dismutase 1 

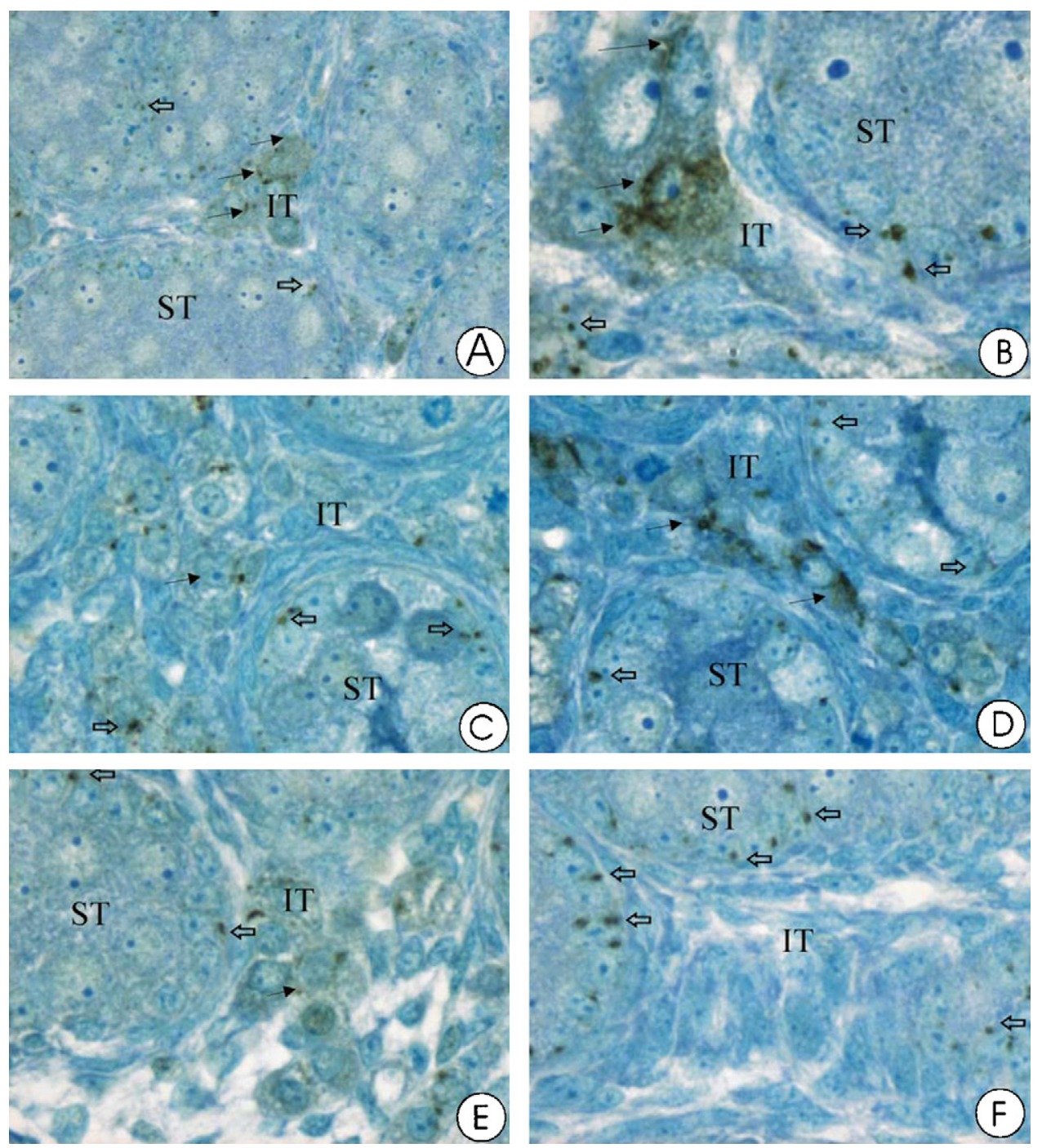

Fig. 4. Effects of in utero exposure to TBT on the immunolocalization of $\mathrm{Cx} 43$ in the fetal testis of the rat. Cx43 was immunolocalized as described in Section 2. Panels A and B are representative of vehicle exposed control rats. Open arrows indicate the presence of Cx43 between Sertoli cells of the developing testis while closed arrows indicate a strong immunoreaction between adjacent interstitial cells. In rats exposed to $10 \mathrm{mg} / \mathrm{kg}$ TBT from gestational days 0 to 19 (panels C and D), $\mathrm{Cx} 43$ immunoreaction was decreased in both Sertoli and Leydig cells. However, the intensity of $\mathrm{Cx} 43$ immunostaining varied between individuals, as noted by the more intense immunostaining shown in panel D. In rats exposed to $10 \mathrm{mg} / \mathrm{kg}$ TBT from gestational days 8 to 19 (panels E and F) there was also an overall decrease in Cx43 immunostaining; however, as with the gestational days 0-19 treatment group, the results indicated individual variability with regards to this effect. Most individuals, as shown in panel E, showed a marked decrease in Cx43 immunostaining while some individuals showed little or no effect (panel D). These results suggest that there are variations in response between individuals, even though there is an overall decrease in Cx43. ST, seminiferous tubules; IT, interstitial Leydig cells. Open arrows indicate Cx43 immunostaining between Sertoli cells. Closed arrows indicate Cx43 immunostaining between interstitial Leydig cells. $500 \times$.

and cytochrome $c$ oxidase subunit I were significantly induced at least 2.5 -fold in TBT exposed fetal testes as compared to unexposed testes while smaller non-significant increases were seen for glutathione $S$-transferase mu2 (2.3-fold), glutathione $S$-transferase alpha 4 (two-fold), cytochrome $c$ oxidase, and subunit IV isoform 1 (1.6-fold); in contrast, increases in these genes were not seen in the fetal ovaries.

\section{Discussion}

In this study, we investigated the effects of in utero exposure to TBT on fetal rat gonads. We chose TBT among other organotins because it is the most commonly used ingredient in many biocides, disinfectants and antifouling products [2]. Furthermore, TBT has been documented to accumulate in the food chain [32]. Although it is known to induce imposex in aquatic invertebrate species, little is known concerning its effects on the mammalian gonads during embryonic development. Thus, the objective of this investigation was to test the hypothesis that exposure to TBT during early development induces damage in the gonad of the fetal rat.

Our quantitative analysis of the number of gonocytes/unit area of the seminiferous tubules revealed a significant decrease only at a maternal dose of $10 \mathrm{mg} / \mathrm{kg}$ (days 8-19). However, both doses and exposure periods resulted in a reduction in the numbers of Sertoli cells, an effect which could potentially reduce 

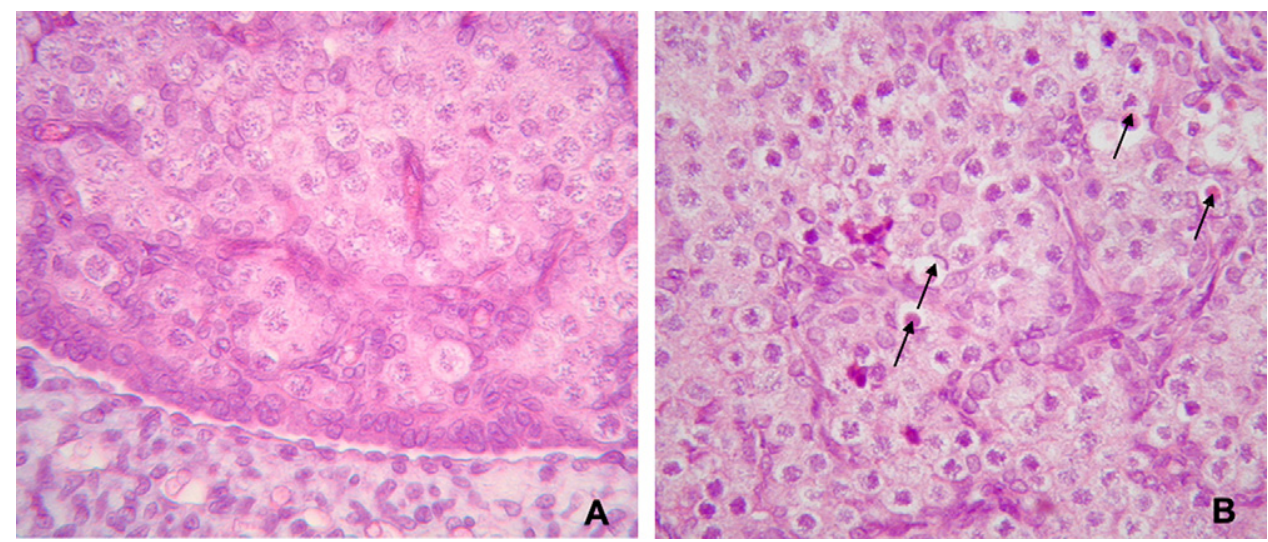

Fig. 5. Ovaries of gestational day 20 fetuses fixed in Bouins solution. (A) Control ovary. (B) Ovary of a fetus exposed to a maternal dose of $20 \mathrm{mg} / \mathrm{kg}$ of TBT (gestation days 8-19). Degenerating germ cells (arrows) appear collapsed, densely stained with hematoxylin and surrounded by a clear space. Note that degenerating cells are more frequent in the treated ovary. $665 \times$.

sperm production in adulthood. The proliferation of Sertoli cells in fetal rats increases progressively from day 16 to a maximum on day 20 [33] and, FSH is the major regulator of Sertoli cell number during fetal development [34]. Our data suggest that in utero exposure to TBT may have inhibited FSH-stimulated Sertoli cell expansion, increased Sertoli cell loss or both.
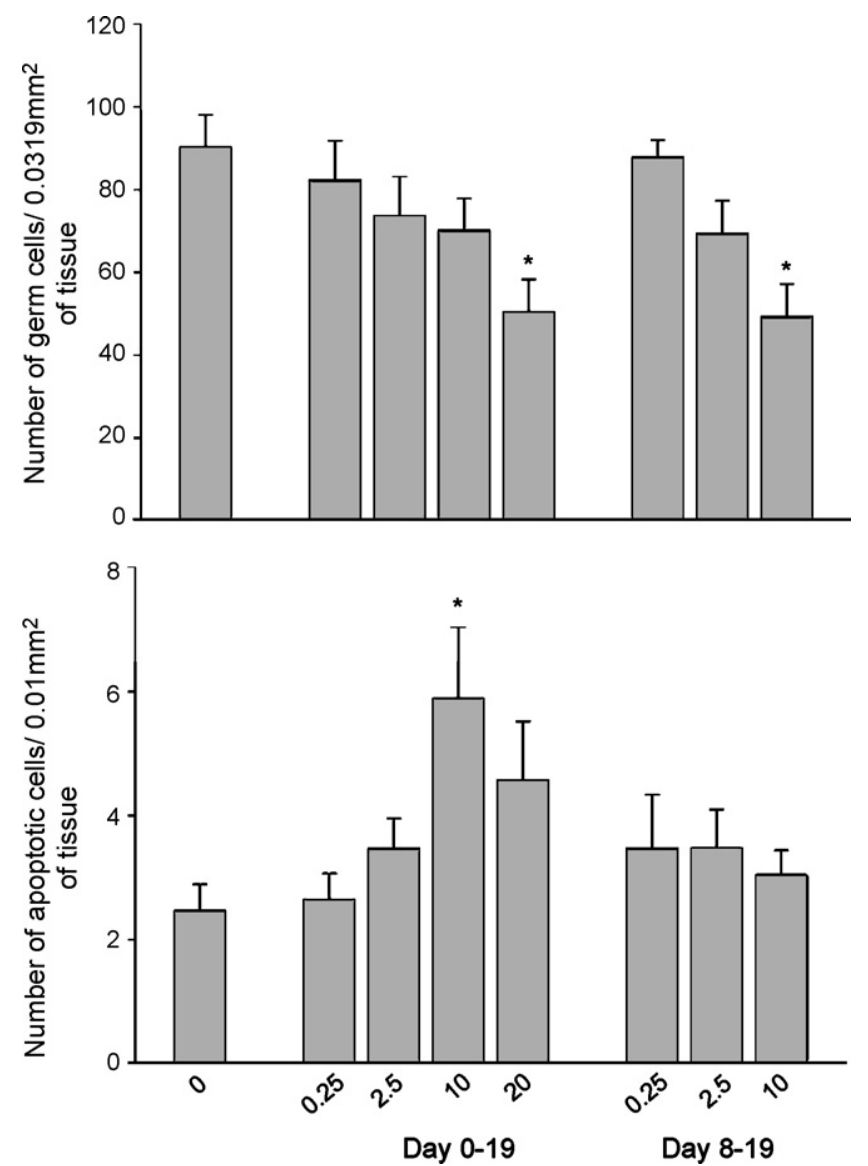

Fig. 6. The effect of in utero exposure to TBT on germ cells in the fetal ovary. (Top) The number of germ cells per $0.0319 \mathrm{~mm}^{2}$ and (bottom) the number of apoptotic cells (per $0.01 \mathrm{~mm}^{2}$ ) in the fetal rat ovary. ${ }^{*}$ Significantly different from control, $p \leq 0.05$; values are mean \pm S.E.M. (standard error of mean). (Bottom) Twenty milligrams per kilogram dose (gestation days $0-19), p=0.1$.
LM and EM analysis of the testis exposed to tributyltin chloride revealed an unusual increase in lipid inclusions within the cytoplasm of gonocytes and particularly within the cytoplasm of Sertoli cells. The molecular mechanisms for the formation of these organotin-induced lipid inclusions remain enigmatic. It could be due to the potent inhibition of mitochondrial oxidative phosphorylation by TBT [35-37], accumulation of acetyl-CoA, and inhibition of fatty acid transport to the mitochondria, hence its accumulation in the cytoplasm [38].

Light and electron microscopic examination also revealed the presence of enlarged intercellular spaces between gonocytes and Sertoli cells in the testes of fetuses exposed to TBT. Several hypotheses have been proposed to account for the numerous toxic actions of organotins, however, the exact molecular mechanism of toxicity of these compounds remains unknown. The inhibition of $\mathrm{Na}^{+}-\mathrm{K}^{+}$-ATPase $[39,40]$ by organotin was suggested to result from a direct interaction of organotins with the

\section{Control Tributyltin chloride, $20 \mathrm{mg} / \mathrm{kg}$}

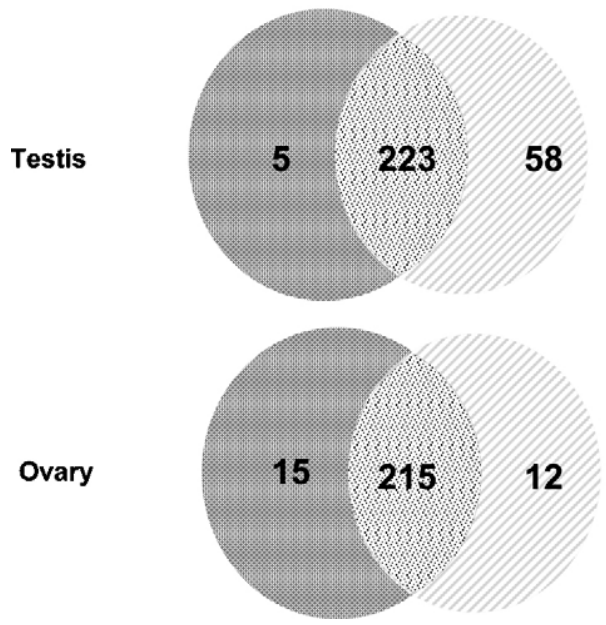

Fig. 7. The number of genes expressed in the gonads of day 20 fetuses after exposure to olive oil (spotted circles) or TBT $(20 \mathrm{mg} / \mathrm{kg}$ ) (dashed circles) from gestational days 0 to 19 . The numbers in the middle areas are the genes that were coexpressed. 
Table 2

Genes that were altered by in utero TBT exposure in the testes of day 20 fetuses

\begin{tabular}{|c|c|c|c|c|}
\hline \multirow[t]{2}{*}{ Upregulated genes } & \multirow[t]{2}{*}{ Accession number } & \multirow{2}{*}{$\frac{\text { Expression }}{\text { Control }}$} & \multirow{2}{*}{$\frac{\text { Intensity }}{20 \mathrm{mg} / \mathrm{kg} \mathrm{TBT}}$} & \multirow[t]{2}{*}{ Fold change } \\
\hline & & & & \\
\hline Integrin beta 1 & U12309 & $0.7 \pm 0.2$ & $1.9 \pm 0.4$ & $2.7^{\mathrm{a}}$ \\
\hline Tumor necrosis factor receptor superfamily, member 1a & M63122 & $0.8 \pm 0.3$ & $2.0 \pm 0.4$ & $2.3^{\mathrm{b}}$ \\
\hline Scavenger receptor class $\mathrm{B}$, member 1 & U76205 & $4.9 \pm 1.6$ & $13.0 \pm 2.0$ & $2.7^{\mathrm{a}}$ \\
\hline Max. protein & D14447 & $1.2 \pm 0.4$ & $2.8 \pm 0.5$ & $2.3^{\mathrm{a}}$ \\
\hline Activating transcription factor 2 & U38938 & $1 \pm 0.2$ & $2.1 \pm 0.5$ & $2.2^{\mathrm{b}}$ \\
\hline Inhibitor of DNA binding 2 & D10863 & $0.8 \pm 0.2$ & $2.9 \pm 0.8$ & $3.5^{\mathrm{a}}$ \\
\hline Inhibitor of DNA binding 3 & D10864 & $3.6 \pm 0.4$ & $7.9 \pm 2.2$ & $2.2^{\mathrm{b}}$ \\
\hline Valosin-containing protein & U11760 & $3.2 \pm 0.8$ & $6.9 \pm 1.2$ & $2.2^{\mathrm{b}}$ \\
\hline Wilms tumor 1 & X69716 & $3.9 \pm 0.9$ & $12.0 \pm 2.0$ & $3.0^{\mathrm{a}}$ \\
\hline v-ets erythroblastosis virus E26 oncogene homolog 1 & L20681 & $0.6 \pm 0.2$ & $1.5 \pm 0.6$ & 2.4 \\
\hline Murine thymoma viral (v-akt) oncogene homolog 2 & D30041 & $1 \pm 0.3$ & $2.7 \pm 0.5$ & $2.6^{\mathrm{a}}$ \\
\hline Expressed in non-metastatic cells 1 & D13374 & $1.1 \pm 0.2$ & $3.3 \pm 0.8$ & $3.0^{\mathrm{a}}$ \\
\hline Expressed in non-metastatic cells 2 & M91597 & $1.4 \pm 0.3$ & $4.0 \pm 0.9$ & $2.8^{\mathrm{a}}$ \\
\hline v-crk sarcoma virus CT10 oncogene homolog (avian) & D44481 & $1.6 \pm 0.3$ & $4.2 \pm 1.1$ & $2.6^{\mathrm{b}}$ \\
\hline v-raf oncogene homolog 1 (murine sarcoma 3611 virus) & X06942 & $1.3 \pm 0.3$ & $3.2 \pm 0.7$ & $2.5^{\mathrm{b}}$ \\
\hline v-akt murine thymoma viral oncogene homolog & D30040 & $1.9 \pm 0.3$ & $5.5 \pm 2.0$ & $2.9^{\mathrm{b}}$ \\
\hline Adenomatous polyposis coli & D38629 & $0.5 \pm 0.1$ & $1.1 \pm 0.2$ & $2.3^{\mathrm{b}}$ \\
\hline Heat shock protein 1 (chaperonin) & X54793 & $4.1 \pm 0.8$ & $8.7 \pm 1.6$ & $2.1^{\mathrm{a}}$ \\
\hline Microsomal glutathione $S$-transferase 1 & J03752 & $4.4 \pm 0.8$ & $11 \pm 2.6$ & $2.5^{\mathrm{a}}$ \\
\hline Cytochrome P450, subfamily 51 & U17697+D87997 & $1.2 \pm 0.1$ & $2.5 \pm 0.5$ & $2.2^{\mathrm{a}}$ \\
\hline Superoxide dismutase 1 & Y00404 & $9.3 \pm 1.7$ & $23.0 \pm 5.0$ & $2.5^{\mathrm{a}}$ \\
\hline Potassium voltage-gated channel, lsk-related subfamily, member 1 & M22412 & $1.3 \pm 0.2$ & $2.8 \pm 0.6$ & $2.1^{\mathrm{a}}$ \\
\hline $\begin{array}{l}\text { Solute carrier family } 25 \text { (mitochondrial carrier; adenine nucleotide } \\
\text { translocator), member } 5\end{array}$ & D12771 & $2.1 \pm 0.3$ & $5.6 \pm 1.9$ & $2.7^{\mathrm{b}}$ \\
\hline Fatty acid binding protein 3 & $\mathrm{~J} 02773$ & $1.1 \pm 0.3$ & $2.8 \pm 0.6$ & $2.6^{\mathrm{a}}$ \\
\hline Vesicle-associated membrane protein 3 & S63830 & $0.6 \pm 0.2$ & $1.5 \pm 0.3$ & $2.6^{\mathrm{a}}$ \\
\hline Cytochrome $c$ oxidase subunit 1 & S79304 & $24 \pm 5.6$ & $61.0 \pm 18.0$ & $2.6^{\mathrm{a}}$ \\
\hline $\begin{array}{l}\text { ATP synthase, } \mathrm{H}+\text { transporting, mitochondrial F1 complex, beta } \\
\text { polypeptide }\end{array}$ & M19044 & $5 \pm 1.2$ & $12 \pm 2.6$ & $2.5^{\mathrm{a}}$ \\
\hline $\begin{array}{l}\text { ATP synthase, } \mathrm{H}+\text { transporting, mitochondrial F0 complex, subunit } \\
\text { b, isoform } 1\end{array}$ & M35052 & $1 \pm 0.1$ & $2.5 \pm 0.7$ & $2.5^{\mathrm{a}}$ \\
\hline Hydroxysteroid dehydrogenase-1,3-beta (predicted) & M38178+M38179 & $14 \pm 3.5$ & $35 \pm 8.3$ & $2.5^{\mathrm{a}}$ \\
\hline Adenylate kinase 3 & D13062 & $0.8 \pm 0.2$ & $2 \pm 0.7$ & $2.4^{\mathrm{b}}$ \\
\hline Calmodulin 3 & $\mathrm{X} 13817$ & $2.9 \pm 0.5$ & $7.7 \pm 3.0$ & $2.7^{\mathrm{b}}$ \\
\hline Ubiquitin-conjugating enzyme E2B & M62388 & $2.4 \pm 0.4$ & $5.1 \pm 0.8$ & $2.2^{\mathrm{a}}$ \\
\hline Heterogeneous nuclear ribonucleoprotein $\mathrm{K}$ & D17711 & $3.9 \pm 0.3$ & $11 \pm 3.7$ & $2.7^{\mathrm{a}}$ \\
\hline Survival of motor neuron 1 & U75369 & $1.2 \pm 0.1$ & $3.1 \pm 0.9$ & $2.5^{\mathrm{a}}$ \\
\hline Set protein & S68987+S68989 & $1.4 \pm 0.2$ & $4.4 \pm 2.0$ & $3.1^{\mathrm{a}}$ \\
\hline Insulin-like growth factor 2 receptor & U59809 & $3.0 \pm 0.5$ & $7.5 \pm 1.4$ & $2.5^{\mathrm{a}}$ \\
\hline Bone morphogenetic protein receptor, type $1 \mathrm{~A}$ & D38082 & $1.1 \pm 0.0$ & $3.1 \pm 1.1$ & $2.8^{\mathrm{a}}$ \\
\hline Luteinizing hormone/choriogonadotropin receptor & M26199 & $0.5 \pm 0.2$ & $1.2 \pm 0.2$ & $2.3^{\mathrm{a}}$ \\
\hline Cholinergic receptor, nicotinic, alpha polypeptide 4 & L31620 & $0.7 \pm 0.3$ & $2.6 \pm 0.8$ & $3.7^{\mathrm{b}}$ \\
\hline Apurinic/apyrimidinic endonuclease 1 & D44495 & $2.8 \pm 0.7$ & $11.0 \pm 5.7$ & $3.8^{\mathrm{b}}$ \\
\hline Ribosomal protein S29 & X59051 & $206 \pm 47$ & $482 \pm 80$ & $2.3^{\mathrm{a}}$ \\
\hline
\end{tabular}

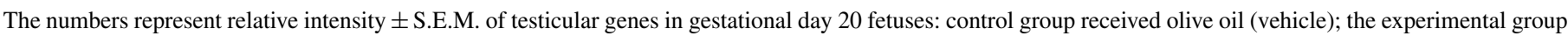

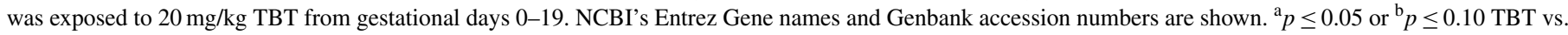
control, Mann-Whitney Rank Sum Test.

plasma membrane and is linked to neurotoxicity [39]. Organotins have also been implicated in the alteration of active and passive membrane properties of pyramidal neurons and changes in the efflux and uptake of L-glutamate and D-aspartate [41]. Most of the ion channel proteins, cell adhesion and transport proteins on the gene array were expressed at background levels in the fetal testes; of those that were altered, the intensities were higher by at least two-fold in the TBT-treated testes compared to control for integrin beta 1 (Accession no. U12309), scavenger receptor $\mathrm{B}$, member 1 (Accession no. U76205), and potassium voltage-gated channel, Isk-related subfamily, mem- ber 1 (Accession no. M22412). Thus, the appearance of large intercellular spaces between gonocytes and Sertoli cells at the highest doses of TBT may reflect changes in the membrane properties of these cells. Also shown in the testes of fetuses exposed to TBT, were distorted and often dilated endoplasmic reticulum in both Sertoli cells and gonocytes. We speculate that this finding could suggest early stages of cell degeneration [42] or large accumulations of gene products [43] in the endoplasmic reticulum, resulting from stress. The expression of a gene coding for valosin-containing protein (Accession no. U1 1760), a protein important for the function of the endoplasmic 
Table 3

Genes that were altered in the ovaries of day 20 fetuses by in utero TBT exposure

\begin{tabular}{|c|c|c|c|c|}
\hline \multirow[t]{2}{*}{ Downregulated genes } & \multirow[t]{2}{*}{ Accession number } & \multirow{2}{*}{$\frac{\text { Expression }}{\text { Control }}$} & \multirow{2}{*}{$\frac{\text { Intensity }}{20 \mathrm{mg} / \mathrm{kg} \mathrm{TBT}}$} & \multirow[t]{2}{*}{ Fold change } \\
\hline & & & & \\
\hline Integrin beta 1 & U12309 & $2.6 \pm 0.4$ & $1 \pm 0.2$ & $-2.6^{\mathrm{a}}$ \\
\hline Cell division cycle 25 homolog B & D16237 & $4.6 \pm 1.1$ & $2 \pm 0.7$ & $-2.3^{\mathrm{b}}$ \\
\hline Heat shock $90 \mathrm{kDa}$ protein 1 beta & S45392 & $65 \pm 11$ & $31 \pm 5.6$ & $-2.1^{\mathrm{a}}$ \\
\hline Gamma-aminobutyric acid (GABA) A receptor, pi & U95368 & $2.1 \pm 0.5$ & $0.6 \pm 0.2$ & $-3.2^{\mathrm{b}}$ \\
\hline Mitogen activated protein kinase kinase 2 & D14592 & $3.3 \pm 0.8$ & $1.6 \pm 0.3$ & $-2.1^{\mathrm{b}}$ \\
\hline Adenylate cyclase 2 & M80550 & $1.7 \pm 0.4$ & $0.8 \pm 0.2$ & $-2.1^{b}$ \\
\hline ADP-ribosylation factor 5 & L12384 & $6.4 \pm 0.9$ & $3.1 \pm 0.8$ & $-2.1^{\mathrm{a}}$ \\
\hline Aminopeptidase Vp165 & U32990 & $4.1 \pm 0.8$ & $2 \pm 0.3$ & $-2.1^{\mathrm{b}}$ \\
\hline
\end{tabular}

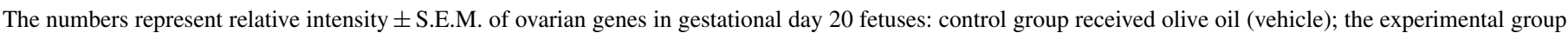

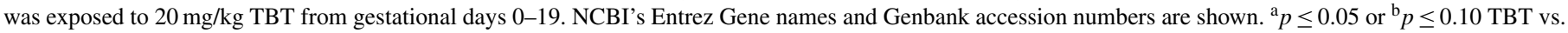
control, Mann-Whitney Rank Sum Test.

reticulum, was increased by 2.2 -fold, lending support to this notion.

In mammals, high levels of TBT have been shown to alter the functions of a variety of endocrine tissues such as the pituitary, endocrine pancreas, gonads and thyroid glands $[8,35,44]$. We therefore examined the number and morphology of Leydig cells in testes of control fetuses and those exposed to TBT. Although the quantitative analysis showed a relative decrease in the number of Leydig cells per unit area of interstitial space in the treated testes (gestation days 0-19) this decrease was not significant. Thus, our results could not substantiate a loss of Leydig cells.

LM examination of fetal ovarian sections revealed a large number of degenerating germ cells. This was particularly evident in rats treated with the highest dose of TBT. Quantitative analysis demonstrated a decrease of germ cells/unit area, which was significant at the highest doses. In ovaries treated with $20 \mathrm{mg} / \mathrm{kg}$ of TBT (gestation days 0-19), a reduction in the number of germ cells of $43.8 \%$ was observed whereas ovaries treated with $10 \mathrm{mg} / \mathrm{kg}$ of TBT (gestation days $8-19$ ) exhibited a $46.1 \%$ decrease. To determine if this decrease was due to apoptosis of germ cells, we stained paraffin sections using the TUNEL technique followed by quantitation of apoptotic cells. This experimental approach demonstrated a trend towards a dose-related increase in the number of apoptotic cells in the ovaries of fetuses exposed during gestation days $0-19$. These results were consistent with the well-documented apoptotic induction of TBT $[45,46]$. However, only the ovaries exposed to $10 \mathrm{mg} / \mathrm{kg}$ of TBT (gestation days 0-19) showed a significant increase in apoptotic (TUNEL positive) cells. This disparity suggests that the exposure to the highest doses of TBT may have induced necrosis, in addition to apoptosis of the germ cells; or that apoptosis had occurred in these cells prior to TUNEL staining.

EM analysis of fetal ovaries showed that the highest doses of TBT favored the formation of iron-containing myelin-like aggregates within the cytoplasm of both germ and stromal cells. This is an indication that in utero exposure to TBT at high doses could result in altered tissue handling and distribution of other metals, in this case, iron. This is in support of previous reports [47] that in utero and lactational exposures to lead or cadmium resulted in changes in organ concentrations of iron and zinc in pups. Whether these alterations represent a disturbance of a given intracellular compartment, i.e., ER, lysosomes, etc., is not clear. However, these myelin structures are indicative of focal degeneration, which may precede apoptosis. In fact, organotinmediated induction of intramembranous aggregation has been reported in human erythrocytes [48].

The immunolocalization studies indicate that cellular communication via $\mathrm{Cx} 43$ type gap junctions is decreased following in utero exposure to high doses of TBT. This effect was observed for both exposure periods in interstitial Leydig cells while the effects on adjacent Sertoli cells appeared to occur only during the 8-19 days exposure period. The presence of $\mathrm{Cx} 43$ gap junctions has been demonstrated by Aravindakshan and Cyr [49] to be essential for cellular communication between Sertoli cells. Cellular coordination, which is mediated by gap junctions, is crucial for the development and function of reproductive tissues [50]. It is therefore significant that these key interactions are reduced or disappear following exposure to TBT. This suggests that cellular communication in the testis may be particularly sensitive to xenobiotic exposure.

In the testes of fetuses exposed to a maternal dose of $20 \mathrm{mg} / \mathrm{kg}$ TBT, the expression of as many as 40 genes was increased by greater than two-fold over control. These genes belong to a wide range of functional classes, including a number of stress response genes. It is plausible that this increased expression reflects at least in part, an increase in mRNA stability, an adaptation of the organism to stress that negatively affects translation [51], in this case, TBT, a known inhibitor of protein synthesis. These fetuses showed significantly smaller weights than controls (even though their placentas were bigger) and delayed bone ossification [16], an indication of a sub-optimal intrauterine environment. Interestingly, in the ovaries of littermates, eight genes were downregulated, suggesting that TBT-induced changes in gene expression patterns are gonad-specific; this observation reiterates the potential gender-specific effects of in utero exposure to toxicants [52]. Differential effects on the fetal testis and ovary may reflect the different events occurring in the two tissues during fetal development; although germ cells in the male and female fetal gonads divide, only the female germ cells enter 

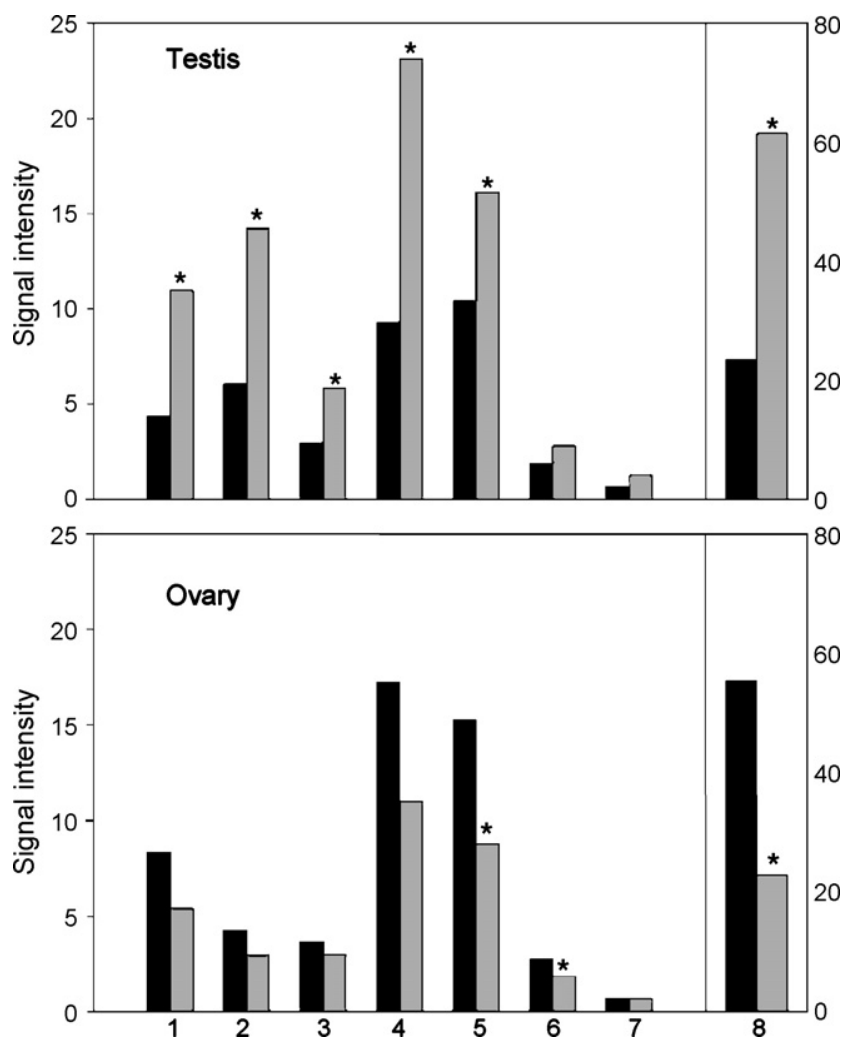

Fig. 8. Relative intensities of expression of stress response-related genes in the testis and ovary of day 20 fetal rats after administration of olive oil (black bars) or TBT $(20 \mathrm{mg} / \mathrm{kg}$ ) (gray bars) from gestational days 0 to 19 . The selected genes (numbers on $X$-axis refer to genes shown in upper-testis and lower-ovary graphs) are: (1) microsomal glutathione $S$-transferase 1, Accession no. J03752; (2) glutathione $S$-transferase, mu2, Accession no. J02592; (3) glutathione $S$-transferase, alpha 4, Accession no. X62660; (4) superoxide dismutase 1, Accession no. Y00404; (5) cytochrome $c$ oxidase, subunit IV isoform 1, Accession no. X14209; (6) cytochrome $c$ oxidase, subunit Va, Accession no. X15030; (7) glutathione peroxidase 4, Accession no. X82679; (8) cytochrome $c$ oxidase subunit I, Accession no. S79304. *Indicates that gene expression was altered by at least 1.5 -fold in at least three out of five replicates. Genes marked with an asterisk whose expression was altered less than two-fold or were altered more than two-fold but were not statistically significant do not appear in Tables 2 and 3 and include for the fetal testis, (2) glutathione $S$-transferase, mu2 (2.3-fold increase), (3) glutathione $S$-transferase, alpha 4 (2.0-fold increase) and (5) cytochrome $c$ oxidase, subunit IV isoform 1 (1.6-fold increase) and for the ovary, (5) cytochrome $c$ oxidase, subunit IV isoform 1 (1.7-fold increase), (6) cytochrome $c$ oxidase, subunit Va (1.5-fold increase), and cytochrome $c$ oxidase subunit I (2.4-fold); all other genes marked with an asterisk can be found in Tables 2 and 3. NCBI's Entrez Gene names and Genbank accession numbers are used.

meiosis while the male germ cells arrest their divisions and only enter meiosis after birth. To better understand mechanisms underlying effects of TBT on fetal gonads it will be important in future studies to examine effects on isolated germ cells and somatic cells at different developmental times.

In conclusion, our results support the notion that TBT is a membrane-active agent that changed the properties of the plasma membrane and induced the formation of intramembranous and lipid aggregates. In utero exposure to TBT altered gene expression profiles differently in the fetal testis and ovary and induced cell loss by apoptosis and perhaps necrosis in germ and somatic cells, which may lead to permanent damage in the adult gonads.

\section{Acknowledgements}

These studies were funded by grant \#58 from the Toxic Substances Research Initiative (TSRI) of Canada and supported by

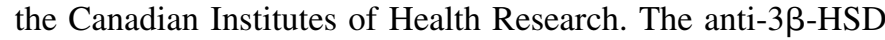
antibody was kindly provided by Dr. Van Luu-The. JMT is a William Dawson Scholar of McGill University and a Scholar of the Fonds de la recherché en santé du Québec. BR is a James McGill Professor of McGill University

\section{References}

[1] Cooney JJ, Weber JH, Sherman LR. Tributyltins in the aquatic ecosystems. In: Majumdar SK, Brenner FJ, Lovich JE, Schalles JF, Miller EW, editors. Biological diversity: problems and challenges. Easton, Penna: The Pennsylvania Academy of Science; 1994. p. 123-35.

[2] Fent K. Ecotoxicity of organotin compounds. Crit Rev Toxicol 1996;26:1-117.

[3] Snoeij NJ, Penninks AH, Seinen W. Biological activity of organotin compounds-an overview. Environ Res 1987;44:335-53.

[4] Wax PM, Dockstader L. Tributyltin use in interior paints: a continuing health hazard. J Toxicol Clin Toxicol 1995;33:239-41.

[5] Forsyth DS, Casey V. Butyltin compounds in retail mollusc products. Food Addit Contam 2003;20:445-52.

[6] Smith BS. Reproductive anomalies in stenoglossan snails related to pollution from marinas. J Appl Toxicol 1981;1:15-21.

[7] Oberdorster E, McClellan-Green P. The neuropeptide APGWamide induces imposex in the mud snail, Ilyanassa obsoleta. Peptides 2001;21:1323-30.

[8] Oberdorster E, Rittschof D, LeBlanc GA. Alteration of [14C]-testosterone metabolism after chronic exposure of Daphnia magna to tributyltin. Arch Environ Contam Toxicol 1998;34:21-5.

[9] Cooke GM. Effect of organotins on human aromatase activity in vitro. Toxicol Let 2002;126(2):121-30.

[10] Acute effect of indoor exposure to paint containing bis(tributyltin) oxide-Wisconsin. MMWR Morb Mortal Wkly Rep 1991;40(17):280-1.

[11] Ross WD, Emmett EA, Steiner J, Tureen R. Neurotoxic effects of occupational exposure to organotins. Am J Psychiatry 1981;138(8):1092-5.

[12] Sloviter RS, von Knebel Doeberitz C, Walsh TJ, Dempster DW. On the role of seizure activity in the hippocampal damage produced by trimethyltin. Brain Res 1986;367(1/2):169-82.

[13] Ghoneum M, Hussein AE, Gill G, Alfred IJ. Suppression of murine natural killer cell activity by tributyltin: in vivo and in vitro assessment. Environ Res 1990;52:178-86.

[14] Delong GT, Rice CD. Tributyltin potentiates 3,3',4,4',5-pentachlorobiphenyl-induced cytochrome p-4501A-related activity. J Toxicol Environ Health 1997;51:131-48.

[15] Whalen MM, Green SA, Loganathan BG. Brief butyltin exposure induces irreversible inhibition of the cytotoxic function on human natural killer cells, in vitro. Environ Res 2002;88:19-29.

[16] Adeeko A, Li D, Forsyth DS, Casey V, Cooke GM, Barthelemy J, et al. Effects of in utero tributyltin chloride exposure in the rat on pregnancy outcome. Toxicol Sci 2003;74(2):407-15.

[17] Cooke GM, Tryphonas H, Pulido O, Caldwell D, Bondy GS, Forsyth D. Oral (gavage), in utero and postnatal exposure of Sprague-Dawley rats to low doses of tributyltin chloride. Part 1. Toxicology, histopathology and clinical chemistry. Food Chem Toxicol 2004;42:211-20.

[18] Heidrich DD, Steckelbroek S, Klingmuller D. Inhibition of human cytochrome P450 aromatase activity by butyltins. Steroids 2001;66:763-9.

[19] Saitoh M, Yanase T, Morinaga H, Tanabe M, Mu YM, Nishi Y, et al. Tributyltin or triphenyltin inhibits aromatase activity in the human granulosa-like tumor cell line KGN. Biochem Biophys Res Commun 2001;289:198-204.

[20] Nakanishi T, Kohroki J, Suzuki S, Ishizaki J, Hiromori Y, Takasuga S, et al. Trialkyltin compounds enhance human CG secretion and aromatase activity in human placental choriocarcinoma cells. J Clin Endocrinol Metab 2002;87:2830-7. 
[21] Omura M, Ogata R, Kubo K, Shimasaki Y, Aou S, Oshima Y, et al. Twogeneration reproductive toxicity study of tributyltin chloride in male rats. Toxicol Sci 2001;64:224-32.

[22] Noland EA, McCauley PT, Bull RJ. Dimethyltin dichloride: investigations into its gastrointestinal absorption and transplacental transfer. J Toxicol Environ Health 1983;12:89-98.

[23] Ema M, Kurosaka R, Amano H, Ogawa Y. Comparative developmental toxicity of butyltin trichloride, dibutyltin dichloride and tributyltin chloride in rats. J Appl Toxicol 1995;15:297-302.

[24] Harazono A, Ema M, Ogawa Y. Pre-implantation embryonic loss induced by tributyltin chloride in rats. Toxicol Lett 1996;89:185-90.

[25] Harazono A, Ema M, Kawashima K. Evaluation of malnutrition as a cause of tributyltin-induced pregnancy failure in rats. Bull Environ Contam Toxicol 1998;61:224-30.

[26] Itami T, Ema M, Amano H, Murai T, Kawasaki H. Teratogenic evaluation of tributyltin chloride in rats following oral exposure. Drug Chem Toxicol 1990;13:283-95.

[27] Ogata R, Omura M, Shimasaki Y, Kubo K, Oshima Y, Aou S, et al. Twogeneration reproductive toxicity study of tributyltin chloride in female rats. J Toxicol Environ Health 2001;63:127-44.

[28] Luu-The V, Lachance Y, Labrie C, Leblanc G, Thomas JL, Strickler RC, et al. Full length cDNA structure and deduced amino acid sequence of human 3ß-hydroxy-5-ene steroid dehydrogenase. Mol Endocrinol 1989;3:1310-2.

[29] Brawer JR, Reichard G, Small L, Schipper HM. The origin ans composition of peroxidase-positive granulaes in cysteamine-treated astrocytes in culture. Brain Res 1994;633:9-20.

[30] Brawer JR, Stein R, Small L, Cissé S, Schipper HM. The composition of Gomori-positive inclusions in astrocytes of the hypothalamic arcuate nucleus. Anat Rec 1994;240:407-15.

[31] Adeeko AO, Li D, Doucet J, Cooke G, Trasler J, Hales B, et al. Gestational exposure to persistent organic pollutants: maternal liver residues, pregnancy outcome and effects on hepatic gene expression profiles in the dam and fetus. Toxicol Sci 2003;72:242-52.

[32] Lau MM. Tributyltin antifoulings: a threat to the Hong Kong marine environment. Arch Environ Contam Toxicol 1991;20:299-304.

[33] Orth JM. Proliferation of Sertoli cells in fetal and postnatal rats: a quantitative autoradiographic study. Anat Rec 1982;203(4):485-92.

[34] Orth JM. The role of follicle-stimulating hormone in controlling Sertoli cell proliferation in testes of fetal rats. Endocrinology 1984;115(4): $1248-55$.

[35] Wada O, Manabe S, Iwai H, Arakawa Y. Recent progress in the study of analytical methods, toxicity, metabolism and health effects of organotin compounds. Sangyo Igaku 1982;24:24-54.

[36] Aldridge WN. The influence of organotin compounds on mitochondrial function. Adv Chem Ser 1976;157:186-95.
[37] Aldridge WN. Phosphorylation. Halide-dependent and halide-independent effects of triorganotin and triorganolead compounds on mitochondrial functions. Biochem J 1977;168:353-64.

[38] Alberts B, Johnson A, Lewis J, Raff M, Roberts K, Walter P. Molecular biology of the cell. 4th ed. New York: Garland Science; 2001. p. 772 [Chapter 14].

[39] Jacobs KS, Lemasters JJ, Reiter LW. Inhibition of ATPase activities of brain and liver homogenates by triethyltin (TET). Dev Toxicol Environ Sci 1983;11:517-20.

[40] Thompson TA, Lewis JM, Dejneka NS, Severs WB, Polavarapu R, Billingsley ML. Induction of apoptosis by organotin compounds in vitro: neuronal protection with antisense oligonucleotides directed against Stannin. J Pharmacol Exp Ther 1996;276:1201-15.

[41] Harikins AB, Armstrong DL. Trimethyltin alters membrane properties of CA1 hippocampal neurons. Neurotoxicology 1992;13:569-81.

[42] de Bruin JP, Dorland M, Spek ER, Posthuma G, van Haaften M, Looman $\mathrm{CW}$, et al. Ultrastructure of the resting ovarian follicle pool in healthy young women. Biol Reprod 2002;66(4):1151-60.

[43] Kaufman RJ. Orchestrating the unfolded protein response in health and disease. J Clin Invest 2002;110(10):1389-98.

[44] Vos JG, Dybing E, Greim HA, Ladefoged O, Lambre C, Tarazona JV, et al. Health effects of endocrine-disrupting chemicals on wildlife, with special reference to the European situation. Crit Rev Toxicol 2000;30:71-133.

[45] Reader S, Moutardier V, Denizeau F. Tributyltin triggers apoptosis in trout hepatocytes: the role of $\mathrm{Ca}^{2+}$, protein kinase $\mathrm{C}$ and proteases. Biochem Biophys Acta 1999;1448:473-85.

[46] Stridh H, Orrenius S, Hampton MB. Caspase involvement in the induction of apoptosis by the environmental toxicants tributyltin and triphenyltin. Toxicol Appl Pharmacol 1999;156:141-6.

[47] Piasek M, Schonwald N, Blanusa M, Kostial K, Laskey JW. Biomarkers of heavy metal reproductive effects and interaction with essential elements in experimental studies on female rats. Arh Hig Rada Toksikol 1996;47:245-59.

[48] Gray BH, Porvaznik M, Flemming C, Lee LH. Organotin-induced hemolysis, shape transformation and intramembranous aggregates in human erythrocytes. Cell Biol Toxicol 1987;3:23-38.

[49] Aravindakshan J, Cyr DG. Nonylphenol alters connexin 43 levels and connexin 43 phosphorylation via an inhibition of the p38 mitogen-activated protein kinase pathway. Biol Reprod 2005;72(5):1232-40.

[50] Juneja JSC, Barr KJ, Enders GC, Kidder GM. Defects in the germ line and gonads of mice lacking connexin43. Biol Reprod 1999;60:1263-70.

[51] Ross J. mRNA stability in mammalian cells. Microbiol Rev 1995;59:423-50.

[52] Gurtoo HL, Motycka L. Effect of sex difference on the in vitro and in vivo metabolism of aflatoxin B1 by the rat. Cancer Res 1976;36:4663-71. 